intensified the guerrilla war, particularly it has become wide scale in Guatemala, Venezuela, Colombia, Nicaragua, Peru and El Salvador.

To resolve long-standing political and military conflict that acquired exact features of the civil war between the government, Left-Radical guerrillas, drug traffickers and ultra right forces, the Colombian President Juan Manuel Santos has chosen the thorny path of national reconciliation by holding negotiations with powerful insurgent organization that enjoyed considerable support of the poor, - The Revolutionary Armed Forces of Colombia - People's Army (FARC-EP). The compromise agreements during 2012-2016 culminated in drawing a comprehensive peace accord, which can settle a pattern of most suitable and civilized settling the sharp military, political and social confrontation within the state.

Keywords: Colombia, civil war, conflict, conservatism, peace agreement, the drug cartel.

\title{
УДК 94(7/8)
}

http://doi.org/10.17721/2521-1706.2017.03.214-223

Павло Кряжев, кандидат педагогічних наук, Ніжинський державний університет ім. М.В.Гоголя

\section{МІСІЯ ПОРТУГАЛЬСЬКОГО МОРЕПЛАВЦЯ ДУАРТІ ПАШЕКУ ПЕРЕЙРИ НАПЕРЕДОДНІ ВІДКРИТТЯ БРАЗИЛІЇ}

Анотація. У статті розглянуто місію португальського мореплавия Дуарті Пашеку Перейри напередодні відкриття Бразилії ескадрою капітана-мора Педру Альвареша Кабрала у 1500 р. Звернено увагу на уривок путівника Перейри, у якому йде мова про розпорядження короля Португалії Жоао II відправити ескадру вказаного мореплавия здійснити розвідку західної землі за Атлантичним океаном. В контексті гіпотези про плавання ескадри Перейри до берегів Бразилії згадано про існування листа магістра Жоао, у якому йде мова про старовинну карту світу португальського мореплавия Перу Ваша да Куньї, на якій була зображена відкрита Кабралом нова земля $і$ західний берег Африки. Акцентовано увагу на ту обставину, що вказана втрачена карта світу могла б прояснити політику короля Жоао II щцодо підписання Тордесільяського договору $з$ королями Кастилії і Арагону у 1494 р. Визначено, щзо напередодні підписання договору у місті Тордесільяс португальський король наполегливо захищав його суверенітет на землі, щзо будуть потенційно відкритими в Південній Атлантиці. Про цей факт свідчить існування Толедської угоди 1480 р.

Зроблено акиент на гіпотетичності плавання ескадри Перейри у 1498 р. з метою розвідки португальського сектору, локалізованому на південному заході від демаркаційного меридіану, щьо було необхідно для забезпечення безпеки морського шляху в Індію і пошуку зручного проміжного пункту, де португальські ескадри на своєму шляху у напрямку Індостану можуть поповнювати провізію.

Ключові слова: географічні відкриття, Португалія, Бразилія, Толедський договір, Тордесільяський договір.

В епоху великих географічних відкриттів постать португальського мореплавця і автора путівника у галузі мистецтва мореплавства «Esmeraldo de Situ Orbis» (в перекладі на українську мову - «Смарагд про положення Землі») (15051508) Дуарті Пашеку Перейри (1460-1533) посідає одне із найважливіших місць. 
Цю людину, по праву, можна назвати великим представником морехідної школи середньовічної Португалії, створеної завдяки наполегливій ініціативі інфанта Генріха (Енрікі) Мореплавця (1394-1460), сина португальського короля Жоао I (1385-1433). Вищезгаданий путівник Перейри яскраво свідчить про його глибокі прикладні знання і морехідний досвід, застосований, зокрема, під час розвідки африканського узбережжя [1]. У путівнику автор згадує, що король Жоао II (14811495) наказав йому серед інших досвідчених капітанів обстежити берег Африки, іiі гавані і річки, включаючи внутрішні райони континенту.

Разом 3 цим, Дуарті Пашеку Перейра у якості досвідченого експерта 3 космографії і мистецтва мореплавства, був свідком підписання 7 червня 1494 р. Тордесільяського договору між Португалією і об’єднаним королівством Кастилії і Арагону, що демаркувала всі землі, які будуть потенційно відкриті цими двома європейськими державами, по меридіану, який взаємно було узгоджено на відстані 370 ліг у західному напрямку від острівного архіпелагу Зеленого Мису (старовинний показник відстані в середньовічній Європі, зокрема в Португалії морська ліга дорівнювала 5 км 920 метрам). Даний факт підтверджується текстом вищезазначеного договору, вміщеного у збірнику документів португальського національного архіву Торре-ду-Томбо [2, С. 80-90].

В контексті 3'ясування місії Перейри на службі португальської корони, доцільно звернути увагу на тривалу полеміку науковців 3 приводу причетності мореплавця до первинного обстеження атлантичного узбережжя Бразилії у 1498 р., до iï офіційного відкриття ескадрою португальського капітана-мора Педру Альвареша Кабрала у 1500 р. Прибічниками цієї гіпотези є дослідники Л. П. да Сілва, Ж. Кортесау, Ф. да Фонсека, та ін. [3-5]. Серед прибічників гіпотези, що мореплавець відвідав атлантичне узбережжя не Південної, а Північної Америки, виділяються дослідники К. де Абреу і С.Е. Морісон, та ін. [6-7].

Полеміка науковців 3 приводу можливого плавання ескадри Перейри до берегів Бразилії у 1498 р. викликана особистим свідченням мореплавця, яке він залишив у своєму путівнику «Esmeraldo de Situ Orbis». Наведемо уривок цієї праці 3 дослівним перекладом 3 португальської на українську мову: «...на третій рік Вашого правління, у 1498 р. Ваша Величносте, розпорядилися відправити мене відкрити західний край, розташований по той бік величного океану. В цьому краю розташована земля з численними великими островами, суміжними 3 нею. Ця земля простягається від лінії північної широти $70^{\circ}$ навпроти північного полюсу... Вона $€$ достатньо заселеною. 3 іншої сторони екватору земля простягається до лінії південної широти $28.5^{\circ}$ навпроти південного полюсу. Ця обширна земля має таку велику довжину, що ні з однієї сторони, ні з іншої сторони неможливо бачити іiі миси... По окружності вся ця земля є округлою. Мені відомо, що зі сторони берега Португальського королівства, миса Фіністерре і будь-якої іншої місцевості Європи, Африки і Азії, ця земля перетинає весь океан у західному напрямку...і простягається на відстань $36^{\circ}$ або 648 ліг шляху. $1^{\circ}$ є еквівалентним 18 лігам...До цієї землі плавали каравели 3 васалами Вашої Величності, по Вашому розпорядженню і дозволу. Вони прямували до вищевказаного берегу, перетинаючи екватор, сягаючи лінії південної широти $28^{\circ}$ навпроти південного полюсу, i відкрили на цій землі багато вишуканих дерев пау-бразіл з багатьма іншими товарами, якими вантажилися каравели» [1, С. 7]. 
Аналіз наведеного фрагменту путівника мореплавця не дає нам підстави достовірно стверджувати, що ескадра Перейри у 1498 р. тримала курс до берегів Бразилії. Даний уривок підтверджує той факт, що після смерті у жовтні 1495 р. короля Жоао II, новий король Португалії Мануель I (1495-1521) продовжував тримати Перейру на королівській службі у якості досвідченого лоцмана i космографа. Оскільки путівник був написаний Перейрою вже після 1505 р., у ньому згадуються португальські каравели, які відвідували береги Бразилії вже після їі офіційного відкриття у 1500 р. ескадрою капітана-мора Педру Альвареша Кабрала.

Слід зауважити, що гіпотеза відносно плавання Перейри до берегів Бразилії до моменту іiї «випадкового відкриття» ескадрою Кабрала, що офіційно прямувала в Індію, потребує підтвердження або спростування шляхом аналізу широкого загалу інших історичних документів, яких, на жаль, або досить замало, або вони втрачені. Потребують, також, аналізу передумови зацікавленості португальської корони закріпити юридично іï панування в південній Атлантиці. Одним із наявних історичних документів, висвітлюючим вірогідність відкриття Бразилії португальцями до 1500 р., яким часто оперують прибічники гіпотези плавання ескадри Перейри до берегів Бразилії, є лист від 1 травня 1500 р. магістра Жоао, учасника вже неодноразово згадуваної експедиції Кабрала. Листа адресовано королю Португалії Мануелю I.

Науковець С. Вітербу ідентифікує магістра Жоао 3 королівським лікарем і астрономом Жоао Фарасом, який був бакалавром медицини, причетним до перекладу 3 латинської на старопортугальську мову трактату римського географа Помпонії Мели (15-60 рр. н.е.) під назвою «Описова географія» [8]. Однак слід зауважити, що не виявлено документів, які б підтвердили ідентифікацію магістра Жоао, учасника експедиції Кабрала, з придворним лікарем і астрономом Жоао Фарасом.

Листа магістра Жоао було знайдено бразильським науковцем Ф.А. де Варнаженом серед документів в державному архіві Португалії Торре-ду-Томбо і вперше опубліковано згаданим дослідником в п'ятому томі журналу бразильського Інституту історії і географії за 1843 р., який було перевидано у 1885 р. [9, С. 364366].

Як свідчить магістр Жоао у своєму листі, він разом 3 двома лоцманами капітана-мора Кабрала і його помічника Санчо де Тоара 27 квітня 1500 р. під час завантаження екіпажами на каравели провізії води і дерева, висадилися на берег нововідкритої землі Вера-Круз і встановили астролябію для вимірювання висоти сонця над лінією горизонту. Це було потрібно для точного визначення південної географічної широти місцеперебування ескадри біля бразильського берегу. Отриманий ними показник склав $17^{\circ}$. У листі вченим, також, було продемонстровано астрономічний малюнок небесного положення зірок південного небесного полюсу. Жоао відзначає, що він спостерігав на нічному небі зірки, які формували «небесний хрест». На думку більшості дослідників, цей факт свідчить про португальське походження назви сузір'я південної небесної півкулі Південний Хрест (на сучасному гербі Бразилії зображене сузір'я Південного Хреста).

Разом 3 цим, магістр Жоао згадує у листі про старовинну карту світу, власником якої був португальський мореплавець XV ст. Перу Ваш да Кунья на 
прізвисько «Бізагуду», в якій, нібито, констатується локалізація відкритої Кабралом нової землі і західного берегу Африки під назвою «Mina». На жаль, до наших днів ця карта не збереглася. Наведемо фрагмент листа магістра Жоао дослівно 3 перекладом 3 португальської на українську мову: «...Сеньйор, локалізація цієї землі, про що Вашій Величності буде повідомлено, наводиться в карті світу Перу Ваша Бізагуди. Ваша Величносте може засвідчити по цій карті місцезнаходження цієї землі. Однак, у цій карті світу відсутнє свідчення про те, чи $\epsilon$ ця земля населеною, чи ні. Ця карта є старовинною і на ній, Ваша Величносте, знайдете, також, напис - «Міна». Вчора майже дізналися про ознаки того, що це $є$ острів і було їх чотири...» [9, С. 365].

Дослідник Г. Вігнауд дотримується точки зору, що карта світу Перу Ваша да Куньї фіксувала результати морських експедицій Дуарті Пашеку Перейри [10, С. 145]. Слід відмітити, що Перу Ваш да Кунья був на службі у португальського короля Жоао II, у часи правління якого побудовано укріплений торговельний форпост або факторію з фортецею Сан-Жоржі-да-Міна на західному березі Африки (1482 р.), а також організовано ряд португальських експедицій 3 метою дослідження африканського узбережжя і пошуку морського шляху до Індії.

Зазначеного мореплавця згадує у третій книзі першої «Декади Азії» (1552) португальський хроніст Жоао де Баррос (1496-1570) [11]. Автор хроніки згадує Кунью в контексті його призначення командувати у 1489 р. ескадрою у складі 20 каравел 3 метою підтримки сенегальського племінного вождя Жолофа, який охрестився і отримав португальське ім'я Жоао Бемоїн. Вказаний вождь запросив у 1488 р. допомогу у португальського короля Жоао II проти його ворогів. Однак справжньою метою експедиції, про що свідчить Жоао де Баррос, був намір португальської корони побудувати фортецю на березі річки Сенегал і створити капітанство (домініон) на цій території. Коли португальці почали будувати фортецю в гирлі Сенегалу, Перу Ваш да Кунья вбив вождя Бемоїна за підозрою у зраді.

Жодна португальська історична хроніка та інші першоджерела не розкривають в деталях перебіг плавання ескадри Перу Ваша да Куньї під час їі повернення до Португалії, тому можна лише робити припущення, що під час повернення із Сенегалу його флотилія могла гіпотетично потрапити під тиск зустрічного вітру, збитися з курсу і супротивною течією відхилитися у напрямку східного берегу Південної Америки. Тільки таким чином можна пояснити появу карти світу Куньї, яку згадує у своєму листі магістр Жоао. В іншому випадку, згадана карта могла бути компіляцією більш ранньої карти світу, але вже не за авторства Куньї. За свідченням Жоао де Барроса, король Жоао II помилував Перу Ваша да Кунью як вбивцю Жоао Бемоїна [11, С. 51]. Цікаво, якими обставинами керувався король під час помилування мореплавця? Яку послугу здійснив Перу Ваш да Кунья, що перевершила факт його причетності до вбивства племінного вождя Жолофа або Жоао Бемоїна? Доцільно вказати, що втрачена карта світу Перу Ваша да Куньї могла б додатково висвітлити політику португальського короля Жоао II щодо підписання Тордесільяського договору у 1494 р.

В контексті з'ясування обставин підписання Тордесільяського договору, слід звернути увагу на свідчення португальських хроністів Жоао де Барроса і Руя да Піни про те, що Христофор Колумб після відкриття Америки і повернення із першої своєї експедиції, прибув 6 березня 1493 р. в Лісабон на зустріч з королем 
Жоао II для з'ясування офіційної позиції суверена відносно нововідкритих земель. Король повідомив Колумбу, що острова, які він відкрив, належать Португалії. При цьому Жоао II відмовився обговорювати це питання з Колумбом, виразивши намір організувати прямі перемовини з королевою Ізабеллою Кастильською і Фернандо II Арагонським [11, С. 56; 12, С. 177-180]. Користуючись умовами договору, укладеного 6 березня 1480 р. в місті Толедо між португальським королем Афонсу V (1438-1477, 1477-1481) і королями-католиками за наслідками династичної війни за кастильський спадок, що закріплював за Португалією домінування в Атлантичному океані, Жоао II розпорядився готувати ескадру з метою силового встановлення португальського суверенітету над землями, відкритими Колумбом. Слід відмітити, що вказаний договір передбачав суверенітет португальської корони над Мадейрою, Азорськими островами, островами Зеленого Мису (Кабо-Верде) i Гвінеєю. Крім того, Португалія отримувала виключне право на морські шляхи в Атлантичному океані південніше Канарських островів, які, в свою чергу, за договором закріплювалися під юрисдикцією королів-католиків [2, С. 42-45]. Право силового захоплення іноземних каравел, що порушували встановлені договором морські кордони двох держав, визначалося грамотою короля Афонсу V від 6 квітня 1480 р., адресованою його сину і майбутньому королю Португалії Жоао II [2, С. 4546]. Ця королівська грамота зобов'язувала принця Жоао відправляти інспекційні ескадри до берегів Гвінеї. Крім того, слід звернути увагу на ту обставину, що в Толедському договорі йшла мова про те, що португальська корона визначила свій суверенітет над землями, які «будуть потенційно відкриті за Канарськими островами і нижче - навпроти Гвінеї» [2, С. 42]. Статті Толедського договору були підтверджені буллою папи римського Сікста IV від 21 липня 1481 р. [2, С. 46-55]. Однак при цьому, папська булла конкретизувала, що Португалія має суверенітет над землями, розташованими в південно-східному напрямку від мису Бохадор.

Умови Толедського договору були в центрі уваги дослідження науковця Ж. Кортесау, який наголосив на тій нормі документу, яка юридично надавала підстави королю Португалії претендувати на землі, що будуть відкриті навпроти Гвінеї. Дослідник висуває припущення, що мова йде про землі, розташовані в західному напрямку від африканського берегу [13, С. 119].

3 метою закріплення «ситуації статус-кво» в Атлантиці, папа римський Александр VI буллою "Inter caetera" від 3 травня 1493 р. підтвердив за Кастилією права на землі, розташовані в західній частині Атлантичного океану. Однак на наступний день вказана булла зазнала виправлення шляхом конкретизації демаркації заморських володінь Кастилії i Португалії. Було проведено демаркаційний меридіан 3 півночі на південь, що розмежовував володіння обох держав на відстані 100 ліг в західному напрямку від Азорських островів і островів Зеленого Мису [2, С. 65-69]. Дослідник В.Д. Лінден зосередив свою увагу на обставинах появи папських булл напередодні підписання Тордесільяського договору [14]. Він, зокрема, з'ясував, що папа римський Александр VI, який був арагонського походження, перебував під значним впливом королів-католиків при прийнятті вищевказаних булл.

У серпні 1493 p. Жоао II, не погоджуючись з буллою Александра VI, відправив посольство королівського десембаргадора (судді) Перу Дініша i секретаря Руя да Піни в Кастилію запропонувати нову редакцію демаркаційної лінії, яка повинна проходити не по меридіану, а по паралелі. Ця паралель повинна 
перетинати Канарські острови. Землі, розташовані на південь від цієї лінії, повинні належати Португалії, у той час, як землі, розташовані на північ від зазначеної лінії, залишаються під юрисдикцією Кастилії. Дослідник Ж. Кортесау висловлює припущення, що такою переговорною пропозицією король Жоао II захищав право на володіння землями атлантичного узбережжя Південної Америки [13, С. 129]. Однак королі-католики не підтримали цю пропозицію.

Остаточна редакція демаркаційного меридіану була узгоджена 7 червня 1494 p. (у день підписання Тордесільяського договору), коли було прийняте узгоджене рішення щодо поділу володінь двох держав по меридіану на відстані 370 ліг у західному напрямку від островів Зеленого Мису, про що нами вже зазначалося вище. Таким, чином, португальській стороні переговорів вдалося переконати кастильських делегатів погодитись на зміну локалізації демаркаційного меридіану у західному напрямку додатково ще на 270 ліг відстані.

Португальські делегати на переговорах у порівнянні з іспанськими були більш обізнаними і досвідченими у питанні визначення демаркації, що підтверджує єпископ і іспанський хроніст Бартоломео де Лас Касас у другому томі його праці "Historia de las Indias" (1517) [15, С. 16]. Одним із таких португальських експертів був Дуарті Пашеку Перейра. Христофор Колумб не делегувався на ці переговори зі сторони Іспанії, оскільки відправився у другу експедицію до Нового Світу (14931496). Доцільно припустити, що мотиви, які спонукали португальську корону сперечатися з іспанською, полягали, перш за все, у намірах Христофора Колумба спрямувати його третю експедицію на південний захід від островів Зеленого Мису у напрямку екватора. Такі наміри генуезького мореплавця викликали велике занепокоєння португальської корони.

Тордесільяський договір зобов'язував кожну із сторін-підписантів відправити протягом 10 місяців після його затвердження одну чи дві каравели, які повинні були з'єднатися біля острову Гран-Канарія. Екіпажами цих каравел повинні бути іспанські і португальські лоцмани, астрономи і моряки в однаковій кількості. Вони повинні були провести рекогносцировку океану і уточнити морські відстані. Ці каравели відбули з Канарських островів у напрямку островів Зеленого Мису, від яких вирушили прямим західним курсом, проводячи вимірювання відстані 370 ліг від лінії меридіану відбуття каравел (острів Санту-Антау), користуючись позначкою - «сінградура» (величина, яка дорівнює відстані, яку долає коравела 3 поставленими вітрилами протягом одного дня) [2, С. 76].

Вказана відстань «370 ліг» була відрахована спільно португальськими i кастильськими лоцманами 3 використанням величини «16.66 ліги на $1^{\circ} »$, еквівалентної 98.62 км. Застосування лоцманами цієї величини підтверджується книгою з мистецтва морської навігації португальського лоцмана Жоао де Ліжбоа «Livro de Marinharia» (1514) [16, C. 29]. Якщо помножити величину «16.66 ліги»на «360`» довготної окружності земного екватору, приходимо до висновку, що більшість космографів на той час оцінювали окружність екватору у 5997.6 морських ліг або 35503 км. Згідно з сучасними геодезичними розрахунками, окружність екватору дорівнює 40075 км. [17, С. 405]. Формула для розрахунку окружності екватору наступна - «D*л». Дослідник Ж.П. Сінтра спробував уточнити шляхом розрахунків координату тордесільяського меридіану по довготі. Згідно його розрахунків, координата даного меридіану складає - «48³5'» [18]. 
Однак поряд із застосуванням величини «16.66 ліги на $1^{\circ}$ », використовувалися y часи Середньовіччя i iнші розрахунки. Наприклад, Христофор Колумб використовував найменший показник величини - «14.16 ліги на $1^{\circ} »[3$, С. 240; 13 , C. 112].

Слід додати, що фундаментальним першоджерелом 3 вміщеними розрахунками i конвертаціями відстаней у градуси геодезичної сітки, яким користувалися мореплавці в XV - XVI ст., $є$ таблиця «Toleta de marteloio» (3 італійської мови перекладається дослівно як «таблиця для морської навігації»). Ця таблиця розміщена в пергаментному атласі венеціанського картографа Андреа Б’янки (1436 р.). Португальським аналогом цього морського регламенту $\epsilon$ «Regimento das leguas» («Статут ліг»). Згідно 3 цим статутом, $1^{\circ}$ дорівнює 17.5 лігам або 103.6 км. [3, C. 72-76]. Іншими словами, відповідно до цього статуту, 360 окружності екватору дорівнювали 6300 лігам (37296 км.). Слід наголосити, що вказаний статут розходився 3 розрахунками португальського космографа Дуарті Пашеку Перейри. В своїй праці “Esmeraldo de Situ Orbis” Перейра вказує, що $1^{\circ}$ дорівнює 18 лігам відстані [1, С. 7]. Ця величина еквівалентна 106.56 км. Таким чином, окружність земної кулі, за даними Перейри, дорівнювала 38361 км. Розрахунки Перейри $є$ більш точними для конвертації відстаней у градуси геодезичної сітки. Оскільки окружність земної півкулі складає $360^{\circ}$ (40075 км.), отримуємо, що $1^{\circ}=111.31$ км., або 18.8 ліги.

Аналіз путівника Перейри дозволяє поставити питання щодо гіпотетичного плавання вказаного мореплавця у напрямку атлантичного узбережжя Південної Америки за розпорядженням короля Мануеля I вже після підписання Тордесільяського договору. Яку Америку він мав на увазі, коли писав: «...по той бік величного океану»? Північну чи Південну Америку? Можна лише виразити впевненість, що португальські мореплавці не могли порушувати положення Тордесільяського договору i перетинати узгоджений демаркаційний меридіан. Плавання у напрямку Північної Америки для португальських мореплавців було під забороною відповідно до вищезазначеного договору. Залишається тільки східний континентальний виступ Південної Америки, іншими словами, Бразилія. Доцільно припустити, що Перейра за наказом короля Мануеля I у 1498 р. здійснив розвідку португальського сектору на південний захід від демаркаційного меридіану, що було необхідно для забезпечення безпеки у подальшому морського шляху в Індію і пошуку зручного проміжного пункту, де португальські ескадри на своєму шляху до Індії можуть поповнювати провізію і відпочивати. У цьому ж році в свою третю експедицію відправився Христофор Колумб, але курс він тримав, як було узгоджено, у напрямку іспанського сектору за демаркаційним меридіаном, досягнувши гирла річки Оріноко (сучасна країна Венесуела). Після відкриття морського шляху в Індію португальським мореплавцем Васко да Гамою, у 1500 р. була організована нова велика експедиція у напрямку цієї далекої країни під командуванням португальського капітана-мора Педру Алвареша Кабрала. Виникає питання у контексті тієї обставини, що Кабрал прийняв несподіване рішення не зупинятися біля острівного архіпелагу Зеленого Мису, як це традиційно робили інші мореплавці в їхній морській навігації, а відразу змінив курс ескадри 3 південного на південно-західний напрямок. Відбулося, таким чином, «офіційне відкриття» Бразилії. 


\section{Література}

1. Pereira D.P. Esmeraldo de Situ Orbis / D.Pereira. - Lisboa: Imprensa Nacional, 1892. - 127 p. [Electronic Resource]. - Mode of Access: https://archive.org/details/esmeraldodesitu00peregoog (last access: May 20, 2017). - Title from the Screen.

2. Alguns documentos do Archivo Nacional da Torre do Tombo acerca das navegações e conquistas portuguezas / [J.R. Coelho]. - Lisboa: Imprensa Nacional, 1892. - 554 p. [Electronic Resource]. - Mode of Access: http://purl.pt/26221/4/hg-8607-a_PDF/hg-8607-a_PDF_24-C-R0150/hg8607-a_0000_1-614_t24-C-R0150.pdf (last access: May 21, 2017). - Title from the Screen.

3. Historia da colonizção portuguesa do Brasil: Em 3 vol. / [Dantas J., Dias C.M., Leite D., Silva L.P.]. - Porto: Litografia Nacional, 1921. - Vol. 1: Os precursores de Cabral. - 276 p. [Electronic Resource]. $\quad-\quad$ Mode of Access: http://objdigital.bn.br/objdigital2/acervo_digital/div_manuscritos/mss90270/mss90270.pdf (last access: May 22, 2017). - Title from the Screen.

4. Historia da colonização portuguesa do Brasil: Em 3 vol. / [Cortezão J., Dias C.M., Mendonça M.L., Leite D., Baião A., Pereira F.M.E.]. - Porto: Litografia Nacional, 1923. - Vol. 2: A epopeia dos litorais. $\quad 440$ p. [Electronic Resource]. - Mode of Access: http://objdigital.bn.br/objdigital2/acervo_digital/div_manuscritos/mss90272/mss90272.pdf (last access: May 22, 2017). - Title from the Screen.

5. Fonseca F. A descoberta do Brasil / F.Fonseca. - Lisboa: Livraria Central de Gomes de Carvalho, 1908. - 346 p.

6. Abreu C. Descobrimento do Brasil e seu desenvolvimento no seculo XVI / C. Abreu. - Rio de Janeiro: Typographia de G. Leusinger \& Filhos, 1883. - 101 p. [Electronic Resource]. - Mode of Access: http://www.brasiliana.usp.br/handle/1918/00158000 (last access: May 22, 2017, 2017). - Title from the Screen.

7. Morison S.E. Portuguese voyages to America in the fifteenth century / S. Morison. - Cambridge: Harvard University Press, 1940. - 151 p.

8. Viterbo S. Trabalhos nauticos dos portugueses nos seculos XVI e XVII / S. Viterbo. - Lisboa: IN-CM, 1998. - 687 p.

9. Varnaghen F.A. Carta de mestre João Physico d'el Rei, para o mesmo Senhor. De Vera Cruz ao $1^{\circ}$ de Maio de 1500 / F.A. Varnaghen // Revista trimensal do instituto hisrotico e geographico do Brasil. - 1885. - T. 5. - P. 364-366. [Electronic Resource]. - Mode of Access: https://drive.google.com/file/d/0B_G9pg7CxKSsTi1xM3dEZHRldlE/view (last access: May 23, 2017). Title from the Screen.

10. Vignaud H. Americ Vespuce: 1451-1512 / H. Vignaud. - Paris: Ernest Leroux, Editeur, 1917. 421 p. [Electronic Resource]. - Mode of Access: https://archive.org/details/americvespuce14500vign (last access: May 23, 2017). - Title from the Screen.

11. Barros J. Decada primeira da Asia / J. Barros. - Lisboa: Impressa per Jorge Rodriguez, 1628. 430 p. [Electronic Resource]. - Mode of Access: http://purl.pt/7030/3/http://purl.pt/7030/3 (last access: May 23, 2017). - Title from the Screen.

12. Serra J.C. Colleccao de livros ineditos de historia portugueza: Em 5 T. / J.C. Serra. - Lisboa: Academia Real das Sciencias, 1792. - T. 2. - 639 p. [Electronic Resource]. - Mode of Access: https://archive.org/details/collecadeliv02corruoft (last access: May 23, 2017). - Title from the Screen.

13. Cortesão J. Historia do Brasil nos velhos mapas: Em 2 T. / J. Cortesão. - Rio de Janeiro: Instituto Rio Branco, 1965. - T. 1. - 436 p. [Electronic Resource]. - Mode of Access: file://C:/Users/admin/Downloads/001968.pdf (last access: May 24, 2017). - Title from the Screen.

14. Linden V.D. Alexandre VI and the demarcation of the maritime and colonial domains of Spain and Portugal, 1493-1494 / V.Linden // The American Historical Review. - 1916. - Vol. 22. - № 1. - P. 120. [Electronic Resource]. https://www.jstor.org/stable/1836192?seq=1\#page_scan_tab_contents (last access: May 24, 2017). - Title from the Screen.

15. Casas F.B. Historia de las Indias: Em 5 vol. / F.B. Casas. - Madrid: Imprenta de Miguel Ginesta, 1875. - Vol. 2. - 520 p. [Electronic Resource]. - Mode of Access: https://archive.org/details/historiaindias02casarich (last access: May 24, 2017). - Title from the Screen.

16. Rebello J.I. de B. Livro de Marinharia. Tratado da agulha de marear de Joao de Lisboa / J.I. de B. Rebello. - Lisboa: Imprensa de Lebanio da Silva, 1903. - 308 p. 
17. Климишин И.А. Элементарная астрономия / И.Климишин. - М: Наука, 1991. - 464 с.

18. Cintra J.P. O mapa das cortes e as fronteiras do Brasil / J.P. Cintra // Boletim de Ciencias Geodesicas de Curitiba. - 2012. - Vol. 18. - № 3. - P. 421-445. [Electronic Resource]. - Mode of Access: http://www.scielo.br/pdf/bcg/v18n3/05.pdf (last access: May 25, 2017). - Title from the Screen.

\section{References}

1. PEREIRA, D.P. (1892) Esmeraldo de Situ Orbis. Lisboa: Imprensa Nacional. [Online] Available from: https://archive.org/details/esmeraldodesitu00peregoog (Accessed: May 20, 2017).

2. COELHO, J.R. et al. (1892) Alguns documentos do Archivo Nacional da Torre do Tombo acerca das navegacoes e conquistas portuguezas. Lisboa: Imprensa Nacional [Online] Available from: http://purl.pt/26221/4/hg-8607-a_PDF/hg-8607-a_PDF_24-C-R0150/hg-8607-a_0000_1-614_t24-CR0150.pdf (Accessed: May 21, 2017).

3. DANTAS, J. et al. (1921) Historia da colonizacao portuguesa do Brazyl. Porto: Litografia Nacional [Online] Available from: http://objdigital.bn.br/objdigital2/acervo_digital/div_manuscritos/mss90270/mss90270.pdf (Accessed: May 22, 2017).

4. CORTEZAO, J. et al. (1923) Historia da colonização portuguesa do Brazyl. Porto: Litografia Nacional. [Online]. Available from: http://objdigital.bn.br/objdigital2/acervo_digital/div_manuscritos/mss90272/mss90272.pdf (Accessed: May 22, 2017).

5. FONSENCA, F. A. (1908) A descoberta do Brazyl. Lisboa: Livraria Central de Gomes de Carvalho.

6. ABREU, C. (1883) Descobrimento do Brazyl e seu desenvolvimento no seculo XVI. Rio de Janeiro: Typographia de G. Leusinger \& Filhos [Online] Available from: http://www.brasiliana.usp.br/handle/1918/00158000 (Accessed: May 22, 2017).

7. MORISON, S.E. (1940) Portuguese voyages to America in the fifteenth century. Cambridge: Harvard University Press.

8. VITERBO, S. (1998) Trabalhos nauticos dos portugueses nos seculos XVI e XVII. Lisboa: INCM.

9. VARNAGHEN, F.A. (1885) Carta de mestre João Physico d'el Rei, para o mesmo Senhor. De Vera Cruz ao $1^{\circ}$ de Maio de 1500. Revista trimensal do instituto hisrotico e geographico do Brasil 5. p. 364-366. [Online] Available from: https://drive.google.com/file/d/0B_G9pg7CxKSsTi1xM3dEZHRldlE/view (Accessed: May 23, 2017).

10. VIGNAUD, H. (1917) Americ Vespuce: 1451-1512. Paris: Ernest Leroux, Editeur [Online] Available from: https://archive.org/details/americvespuce14500vign (Accessed: May 23, 2017).

11. BARROS, J. (1628) Decada primeira da Asia. Lisboa: Impressa per Jorge Rodriguez [Online] Available from: http://purl.pt/7030/3/http://purl.pt/7030/3 (Accessed: May 23, 2017).

12. SERRA, J.C. (1792) Colleccao de livros ineditos de historia portugueza. Lisboa: Academia Real das Sciencias [Online] Available from: https://archive.org/details/collecadeliv02corruoft (Accessed: May 23, 2017).

13. CORTESAO, J. (1965) Historia do Brazyl nos velhos mapas. Rio de Janeiro: Instituto Rio Branco [Online] Available from: file:///C:/Users/admin/Downloads/001968.pdf (Accessed: May 24, 2017).

14. LINDEN, V.D. (1916) Alexandre VI and the demarcation of the maritime and colonial domains of Spain and Portugal, 1493-1494. The American Historical Review. 22 (1). P. 1-20. [Online] Available from: https://www.jstor.org/stable/1836192?seq=1\#page_scan_tab_contents (Accessed: May 24, 2017).

15. CASAS, F.B. (1875) Historia de las Indias. Madrid: Imprenta de Miguel Ginesta [Online] Available from: https://archive.org/details/historiaindias02casarich (Accessed: May 24, 2017).

16. REBELLO, J.I. de B. (1903) Livro de Marinharia. Tratado da agulha de marear de Joao de Lisboa. Lisboa: Imprensa de Lebanio da Silva.

17. KLYMYSHYN, I.A. (1991) Elementarnaya astronomyya. - M: Nauka.

18. CINTRA, J.P. (2012) O mapa das cortes e as fronteiras do Brazyl. Boletim de Ciencias Geodesicas de Curitiba. 18 (3). p. 421-445. [Online] Available from: http://www.scielo.br/pdf/bcg/v18n3/05.pdf (Accessed: May 25, 2017).

Надійшла до редколегії 01.03.2017 
Pavel Kryazhev, Ph.D. (Pedagogical Sciences), Mykola Gogol State University of Nizhyn

\title{
MISSION OF PORTUGUESE NAVIGATOR DUARTE PACHECO PEREIRA ON THE EVE OF BRAZIL DISCOVERY
}

\begin{abstract}
In the article we examine the mission of a Portuguese navigator Duarte Pacheco Pereira on the eve of Brazil discovery by the squadron of major-captain Pedro Alvares Cabral in 1500. We emphasized on the extract of Pereira guide-book which narrates about order of portuguese monarch Manuel I to dispatch the squadron of indicated navigator for realization reconnaissance mission towards western land behind the Atlantic ocean. Within the context of hypothesis about the voyage of Pereira squadron towards coasts of Brazil we mention the existence of the magister Joao's letter which tells about the ancient world map of the Portuguese navigator Pero Vaz da Cunha. This map represented new land which has been discovered by the squadron of major-captain Cabral. Also the map represented the western coast of Africa. We draw attention to the circumstance that this lost world map could clarify politics of the Portuguese monarch Joao II concerning the signing of Tordesillas treaty with the kings of Castilla and Aragon in 1494. We determined that on the eve of the abovementioned treaty signing the Portuguese monarch had protected his sovereign jurisdiction on the lands which would be discovered on the territory of the South Atlantic Ocean water zone. This fact is confirmed by the signing of Toledo treaty in 1480.

We as well emphasize that Pereira had realized the reconnaissance of the Portuguese sector of the Atlantic Ocean towards Southwest direction behind the demarcation meridian in 1498. This act has been provoked by the necessity to ensure safety of the Portuguese sea navigation towards India.
\end{abstract}

Key words: geographic discoveries, Portugal, Brazil, Toledo treaty, Tordesillas treaty.

УДК 94(72):330.3+330.5+332.05

Тетяна Перга

кандидат історичних наук, старший науковий співробітник ДУ «Інститут всесвітньої історії НАН України», м.Київ

\section{ОСОБЛИВОСТІ СОЦАЛЬНО-ЕКОНОМІЧНОГО РОЗВИТКУ МЕКСИКИ У 40-70-Х РР. ХХ СТОЛІТТЯ}

\begin{abstract}
Анотація. Досліджується сочіальна та економічна політика Мексики 1940-1970-х рр. Проаналізовано передумови економічного зростання Мексики, щуо почали формуватися ще в 1930-х - 1940-х рр., зокрема: аграрна та освітня реформи, націоналізація найважливіших галузей промисловості та формування державного сектору, розширення експорту під час Другої світової війни. Розкрито причини прийняття та головні напрями політики імпортозамінної індустріалізаиії, серед яких: заохочення національних приватних капіталовкладень, захист їх від іноземних конкурентів; розширення державного сектора в промисловості иляхом націоналізаціі окремих підприємств $і$ галузей, будівництва державних підприємств; збільшення державного фінансування $i$ кредитування промисловості. Проаналізовано позитивні результати розвитку Мексики у 1940-1970-х рр.: високі темпи економічного зростання, стабільність начіональної валюти, низька інфляція, розширення середнього класу, реалізація багатьох інфраструктурних та соиіальних проектів. Доведено, щзо не дивлячись на помітні короткострокові успіхи, обрана урядом Мексики стратегія
\end{abstract}

